\title{
QUANTITATIVE DETERMINATION OF ENDOSPERM MODIFICATION AND ITS RELATIONSHIP TO THE CONTENT OF 1,3:1,4- $\beta$-GLUCANS DURING MALTING OF BARLEY
}

\author{
by \\ STEN AASTRUP \\ Department of Biotechnology, Carlsberg Research Laboratory, \\ Gamle Carlsberg Vej 10, DK-2500 Copenhagen, Valby \\ and \\ KENNETH ERDAL \\ Department of Brewing Chemistry, Carlsberg Research Laboratory, \\ Gamle Carlsberg Vej 10, DK-2500 Copenhagen, Valby
}

Keywords: Modification, malting, cell wall breakdown, $\beta$-glucan, endo- $\beta$-glucanase, barley, Calcofluor, image analysis, fluorescence

The modification of barley endosperm during malting was quantitatively determined using the fluorochrome Calcofluor. The technique involved image analyser measurement of the area of residual cell wall material in longitudinally cut half seeds. The average modification was found to be highly correlated to both $1,3-1,4-\beta$ glucan content and endo- $\beta$-glucanase activity, while a low correlation coefficient was obtained between modification and acrospire length of individual seeds.

\section{INTRODUCTION}

Malting of barley can be defined as a controlled germination of the barley seed. Malting is characterised by both coleoptile (acrospire) and rootlet growth, the production of hydrolytic enzymes, and a progressive change in the structure of the starchy endosperm. The term modification has been used to describe the physical change in the texture of the endosperm. The shard" texture of the ungerminated seed is gradually transformed into the "soft " texture of the green malt. This transformation is commonly ascribed to disintegration of the $\beta$-glucanrich endosperm cell walls. A progressive decrease in soluble $\beta$-glucan is observed during malting (23) and during kilning a further

Abbreviation: Mixed-linked 1,3:1,4- $\beta$-glucans, in the present communication referred to as $\beta$-glucans. 
reduction in extractable $\beta$-glucan is seen (8). In beer brewing the presence of undegraded $\beta$ glucan in the wort results in an increase of wort filtration time (7) and when substantial amounts of $\beta$-glucan persist in the fermented beer, gelatinous precipitates can occur which affect the final filtration of the beer (14). It is therefore essential to control the $\beta$-glucan level during malting. In the present study $\beta$-glucan levels during malting were followed by direct enzymatic determination (5). The disintegration of cell walls during endosperm modification was followed by a method based on the principle that intact endosperm cell walls of barley are stained specifically by the fluorochrome Calcofluor (10).

\section{MATERIALS AND METHODS}

\subsection{Plant material}

Hordeum vulgare cv. Nordal from the 1977 Danish harvest was sieved and according to malt house specifications seeds larger than $2.5 \mathrm{~mm}$ in diameter were used in the experiment. The protein content was $12.1 \%$ d.m.

\subsection{Pilot malting}

$16 \mathrm{~kg}$ of barley was steeped and germinated at $16-17^{\circ} \mathrm{C}$ in a rotating stainless steel net drum. Steeping was carried out by alternating periods of water and air, followed by dropwise addition of water until a moisture content of $43 \%$ was reached. During germination this moisture content was maintained by dropwise addition of water. After $6 \frac{1}{2}$ days of germination $15 \mathrm{~kg}$ of green malt was kilned and $5 \mathrm{~kg}$ of green malt was allowed to germinate for a further $31 / 2$ days. The kilning programme used was as follows: 011 hours, $16-50^{\circ} \mathrm{C}$; $11-14$ hours, $50-80^{\circ} \mathrm{C}$; 14-17 hours, $80^{\circ} \mathrm{C}$. Samples of green malt $(500$ g) were taken daily. A sample was also taken from the top layer of the malt during kilning. These samples were immediately frozen in liquid nitrogen and freeze-dried at a final temperature of $-2{ }^{\circ} \mathrm{C}$. Freeze-dried samples were stored at $-20^{\circ} \mathrm{C}$.

\section{3. $\beta$-glucan determination}

Total and insoluble $\beta$-glucan was measured as described by ANDERson et al. (5). The method involved enzymatic hydrolysis of the $\beta$-glucans by means of a specific 1,3:1,4- $\beta$-4-endohydrolase (EC 3.2.1.73) followed by hydrolysis of the liberated oligosaccharides to glucose, which was measured by a glucose oxidase-peroxidase reagent (GOD-Perid ${ }^{\mathrm{R}}$, Boehringer Mannheim,

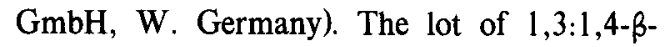
glucan 4-endo-hydrolase used in the present study has been previously described (1). The $\beta$ glucan content was calculated as glucose equivalents and all results represent the mean of triplicate determinations. The water-soluble $\beta$ glucan content was calculated as the difference between the total and the water-insoluble $\beta$ glucan. Extractions were performed both at $65^{\circ} \mathrm{C}$ and $75^{\circ} \mathrm{C}$.

\subsection{Endo- $\beta$-glucanase determination}

Endo- $\beta$-glucanase activity was measured viscometrically by the method proposed by $\mathrm{S}_{\mathrm{AN}}$ DEGREN and ENEBO (25) for wcellulase nation in barley. Barley $\beta$-glucan prepared according to the method of PrEECE and MACKENZIE (24) was used as substrate. Viscosity was measured using an Ostwald Viscometer (Brand, W. Germany). Activity was calculated from the increase of reciprocal specific viscosity, $\Delta\left(\eta_{\mathrm{sp}}{ }^{-1}\right)$, as $1000 \times \Delta\left(\eta_{\mathrm{sp}}^{-1}\right) \times \mathrm{min}^{-1} \times \mathrm{g}^{-1}$.

\subsection{Quantitative determination of endosperm modification}

\subsubsection{Fixation of the seeds}

Samples of the freeze-dried barley green malt and kilned malt were fixed in $10 \%$ periodatelysine-paraformaldehyde (11) and stored at $-20^{\circ} \mathrm{C}$ until use.

\subsubsection{Visualization of the cell walls}

Cell wall breakdown measurements were based upon the Calcofluor technique $(10,12)$. In the present study the method involved: 1) Sectioning of the seeds by a dorsoventral longitudinal cut $0.5 \mathrm{~mm}$ from the ventral furrow. 2) Mounting of the smallest halves in a modelling clay template provided with ten holes. 3) A light pressure to keep the "half seeds « in place. 4) Staining of the cell walls with $0.1 \%$ aqueous Calcofluor White M2R New (Cyanamid, USA) for 1-2 min. 5) Washing of the 


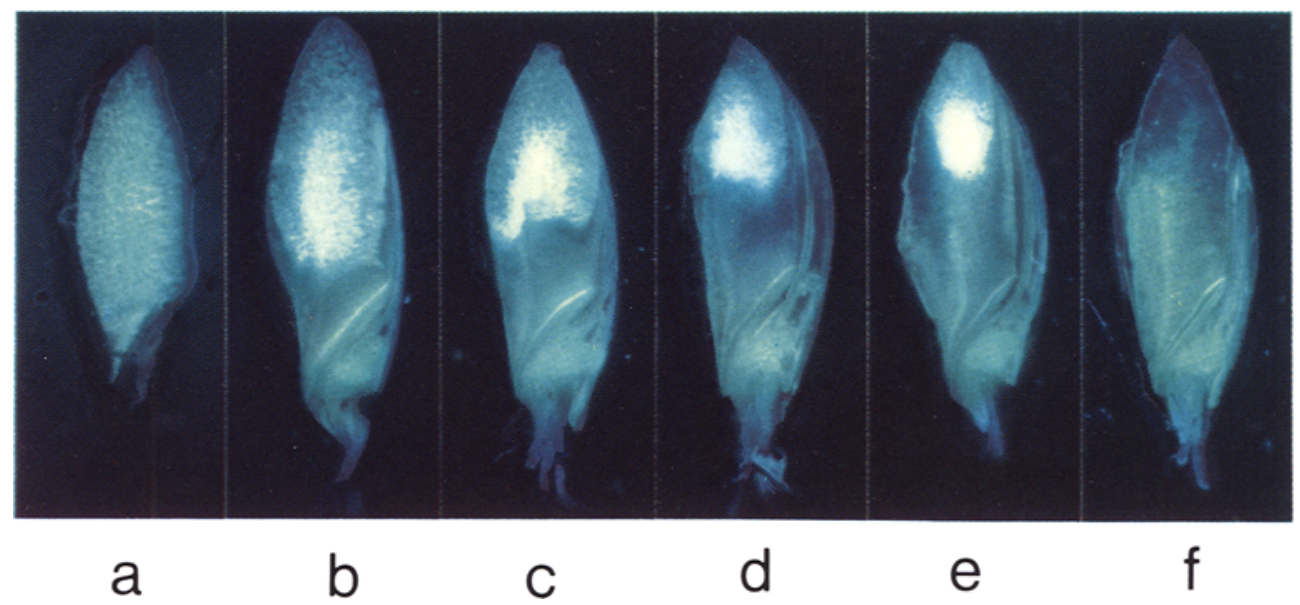

Figure 1. »Half seeds « stained with Calcofluor showing increasing endosperm modification.

a: unmodified, b-e: modified $25 \%, 40 \%, 60 \%$ and $75 \%$, respectively. f: completely modified. The shalf seeds « were photographed using a Carlsberg Macrofluorescence Unit attached to an American Optical Stereo Star Zoom microscope.

stained whalf seeds $«$ in $70 \% \mathrm{v} / \mathrm{v}$ aqueous ethanol followed by drying in a stream of air. 6) Counterstaining with $0.1 \%$ Fast Green F. C. F. (Gurr/Searle, England) for about $1 \mathrm{~min}$ to increase the contrast between the cell walls and the other endosperm components. 7) Preservation of the stained »half seeds $«$ using a thin layer of nail polish. 8) Examination under a microscope provided with U.V.-light (Figure 1).

\subsubsection{Image analysis}

The Calcofluor stained whalf seeds« were placed one by one under a Plan $2.5 \mathrm{X}$ objective on a Reichert Polyvar microscope (Reichert, Austria) using specially designed fluorescence optics (SWP-400 nm exciter filter, BS $410 \mathrm{~nm}$ dichroic mirror and KV-418 emission filter, Optisk Laboratorium, Denmark). The image of the "half seed" was further enlarged by an adjustable ocular, giving a final magnification of $28 \mathrm{X}$, before it was transferred via a Plumbicon television camera to the screen of an image analyser (Imanco Quantimet 720, Cambridge Instruments, England) Figure 2. The visual display is composed of 500,000 picture points each of which can register 64 different "grey" values giving a resolution about twice that of a normal television display. The television image of the "half seed" (Figure 3) was analysed electronically in the image analyser where counting, area measurement, circumference measurement etc. can be made at each "grey « level (19). Figure 3, I illustrates the display of a whalf seed image composed of 152,212 picture points.

Calcofluor binds to $\beta$-glucans as well as to cellulose ( $\beta$-1,4-glucan) (17). Therefore in the present study a manually operated light-pen editor was used as it was not possible in an automatic analysis to discriminate between the "grey» values of endosperm cell walls and the cellulose containing cell walls of the scutellum and embryo (Figures 1 and 3). To quantify measurement of cell wall breakdown the lightpen editor was used to discriminate the area of endosperm with intact cell walls (Figure 3, I, a) from the total endosperm area (Figure 3, I, $a+b$ ). These areas were determined by the number of picture points enclosed by the lightpen editor, shown as a white field on the display after detection. For the example shown in Figure 3 the intact cell wall area and the total endosperm area was composed of 33,176 (Figure 3, II, a) and 103,172 (Figure 3, III, a + b) picture points, respectively.

The modification percentage with regard to 


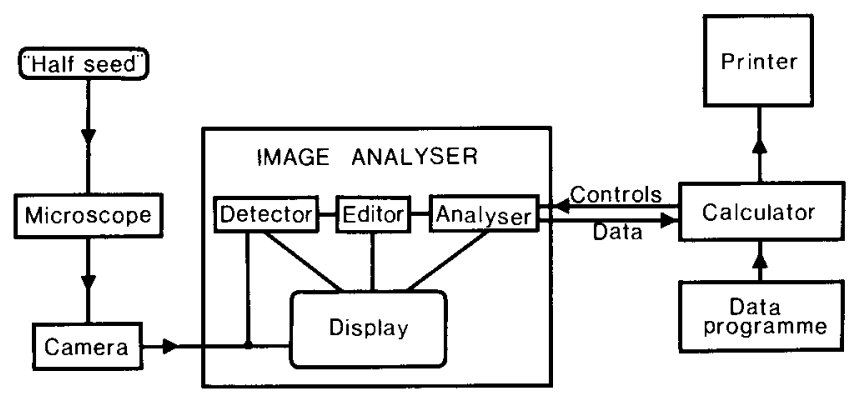

Figure 2. Total image analyser system, simplified block diagram.

cell wall breakdown in an individual seed is defined as $M_{i}=100 b /(a+b) \%$, where $b$ is the area of the endosperm with disintegrated cell walls (Figure 3, b) and $a+b$ is the area of the total endosperm (Figure 3, $a+b$ ).

The complete image analysis procedure was monitored by a Hewlett Packard 9835 A calculator (Figure 2). 50 seeds $(n=50)$ were analysed from each germination day, and from these individual measurements $\left(\mathrm{M}_{\mathrm{i}}, \mathrm{i}=1-50\right)$ the average modification percentage $\left(M_{a}=\Sigma M_{i} / n\right)$, the standard deviation of distribution (s) and the $95 \%$ confidence limits of average $\left(M_{a} \pm 2 s \sqrt{n}\right)$ were calculated.

\subsection{Acrospire determination}

Acrospire measurements were made on the same whalf seeds" as used for the determination of cell wall breakdown (see 2.5). The acrospire length was expressed as the length of acrospire relative to seed length. Four classes were employed: Acrospire less than or equal to $1 / 4$ of the seed. Acrospire greater than $1 / 4$ but less than or equal to $1 / 2$ of the seed. Acrospire greater than $1 / 2$ but less than or equal to $3 / 4$ of the seed. Acrospire greater than $3 / 4$ of the seed. In ungerminated seeds the acrospire was always less than $1 / 4$ of the seed.

\subsection{Visual determination of modification}

The modification percentage was judged visually by means of a specially designed fluorescence microscope, the Carlsberg Macrofluorescence Microscope (13). $\mathrm{M}_{\mathrm{i}}$ was judged by comparison of the given »half seed« with a
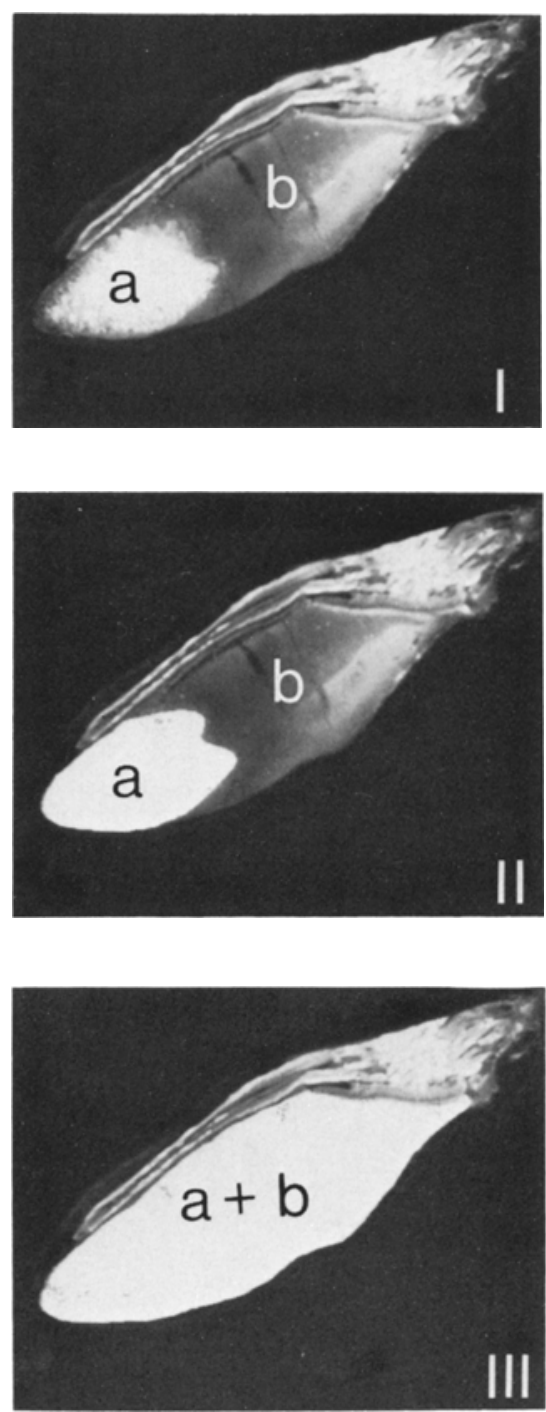

Figure 3. Individual steps (I-III) of the quantitative determination of endosperm modification as displayed on the screen of the image analyser.

I) Image of the whalf seed" showing fluorescing intact cell walls (a) and non-fluorescing disintegrated cell walls (b) before electronic detection. II) Detected area of intact cell walls (a) enclosed by the light-pen editor. III) Detected area of total endosperm $(a+b)$ enclosed by the light-pen editor.

standard slide composed of six »half seeds « with $M_{i}=10,20,40,60,80$ and $90 \%$. From the single seed "measurements" the $\mathrm{M}_{\mathrm{a}}$ and the $95 \%$ confidence limits of average were calculated. 


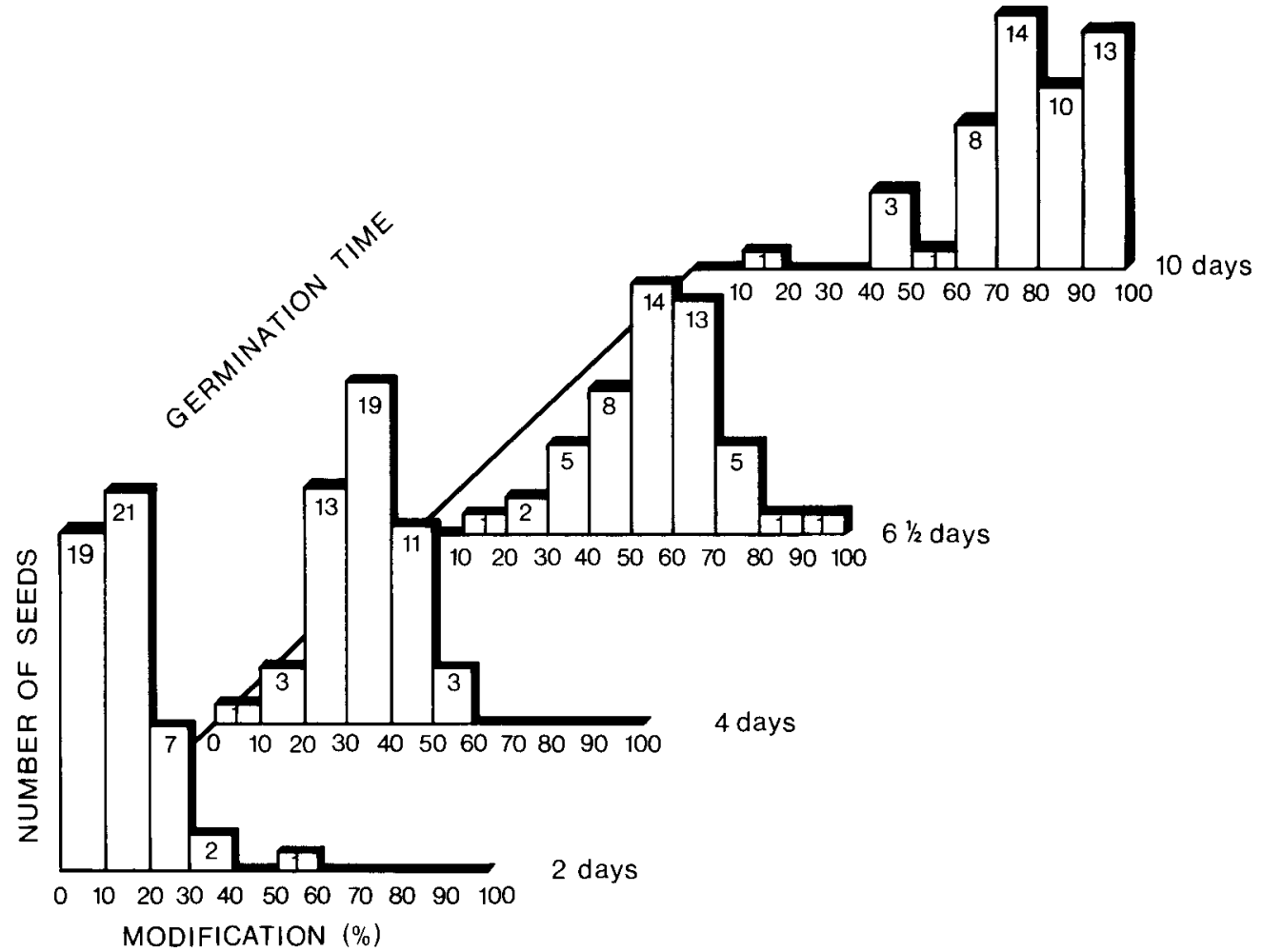

Figure 4. Distribution of endosperm modification percentage $\left(\mathrm{M}_{\mathrm{i}}\right)$ in samples of 50 seeds.

Germination time: $2,4.6 \%$ and 10 days.

\subsection{Standard malt analysis}

Moisture content, extract content, extract difference, diastatic power, Kolbach index and colour were determined according to the procedures recommended by the Analysis Committee of the European Brewing Convention (4). Nitrogen was determined by Kjeldahl analysis in a Kjel-Foss Automatic 16.210 (A/S N. Foss Electric, Hillerød, Denmark). Viscosity was determined with a Haake Kugelfall Viskosimeter (Haake, K. G., Berlin-Steglits, W. Germany).

\section{RESULTS}

\subsection{Error in the use of the light-pen editor}

Errors resulting from the manual operations involved in the use of the light-pen editor were tested in two ways. Firstly by measuring a given seed $\left(M_{i}\right.$ approx. equal to 70$) 50$ times, and secondly by duplicate measurements of a set of 50 seeds with a one month interval. The repeated measurements of the same seed resulted in $M_{a}$
$=70.0 \%$ with $\mathrm{s}=0.5 \%$. The duplicate measurement of the same set of 50 seeds resulted in $\mathrm{M}_{\mathrm{a}}=67.2 \pm 4.9$ and $66.6 \pm 5.0$, respectively, a deviation of less than $1 \%$. These results indicate that errors due to the handling of the light-pen editor are small.

\subsection{Endosperm modification during malting}

In order to study endosperm modification during malting, daily samples of 50 seeds were taken during the course of a 10 days pilot malting.

The seed to seed variation of $\mathrm{M}_{\mathrm{i}}$ was large as illustrated in Figure 4 for four germination days covering the entire germination time. After two days of germination the first seeds with modified endosperm were apparent. The majority of seeds were either unmodified or slightly modified giving as expected an oblique distribution. One seed, however, showed more than $50 \%$ modification. Normal distributions were observed after 
Table I

Endo- $\beta$-glucanase activity, $\beta$-glucan content, acrospire length and $M_{a}$ during 10 days of malting.

\begin{tabular}{|c|c|c|c|c|c|c|c|c|}
\hline \multirow[t]{2}{*}{$\begin{array}{c}\text { Germi- } \\
\text { nation } \\
\text { time } \\
\text { (days) }\end{array}$} & \multirow[t]{2}{*}{$\begin{array}{l}\text { Endo- } \beta \text { - } \\
\text { glucanase } \\
\text { activity } \\
\text { (arb. units) }\end{array}$} & \multirow[t]{2}{*}{$\begin{array}{c}\text { Total } \\
\beta \text {-glucan } \\
\text { (\% of dry } \\
\text { flour })\end{array}$} & \multicolumn{4}{|c|}{$\begin{array}{l}\text { Distribution of } \\
\text { acrospire } \\
\text { length (L) } \\
(\%)\end{array}$} & \multicolumn{2}{|c|}{$\begin{array}{c}\text { Endosperm } \\
\text { modification } \% \\
\left(\mathrm{M}_{\mathrm{a}}, \mathrm{n}=50\right)\end{array}$} \\
\hline & & & $\mathrm{L} \leqq 1 / 4$ & $<\mathrm{L} \leqq 1 / 2$ & $<\mathrm{L} \leqq 3 / 4$ & $<\mathrm{L}$ & sample I & sample II \\
\hline 0 & 32 & 4.12 & $100^{4}$ & 0 & $\overline{0}$ & 0 & 0.0 & \\
\hline 0.1 & 28 & 4.33 & 100 & 0 & 0 & 0 & 0.0 & \\
\hline 2 & 129 & 4.28 & 100 & 0 & 0 & 0 & $13.9 \pm 3.1$ & $14.2 \pm 2.1$ \\
\hline 3 & 316 & 4.20 & 23 & 77 & 0 & 0 & $19.3 \pm 3.7$ & \\
\hline 4 & 571 & 3.40 & 6 & 33 & 61 & 0 & $34.6 \pm 3.0$ & \\
\hline 5 & 1007 & 2.30 & 0 & 0 & 64 & 36 & $45.2 \pm 3.5$ & \\
\hline 6.5 & 1344 & 1.84 & 0 & 3 & 48 & 49 & $55.2 \pm 4.4$ & \\
\hline 7 & 1384 & 1.62 & 0 & 7 & 32 & 61 & $59.6 \pm 3.7$ & \\
\hline 8 & 1391 & 1.36 & 0 & 0 & 32 & 68 & $67.2 \pm 4.9$ & $68.3 \pm 5.6$ \\
\hline 9 & 1501 & 1.22 & 0 & 0 & 15 & 85 & $75.3 \pm 3.7$ & \\
\hline 10 & 1576 & 1.10 & 0 & 0 & 12 & 88 & $78.5 \pm 5.0$ & $76.2 \pm 4.0$ \\
\hline
\end{tabular}

L: Acrospire length relative to seed length.

four and six and a half days of germination. After ten days most of the seeds had $\mathrm{M}_{\mathrm{i}}>75 \%$ giving again an oblique distribution.

The average modification percentage $\left(\mathrm{M}_{\mathrm{a}}\right)$ and the $95 \%$ confidence limits $\left(M_{a} \pm 2 s \sqrt{n}\right)$ of the

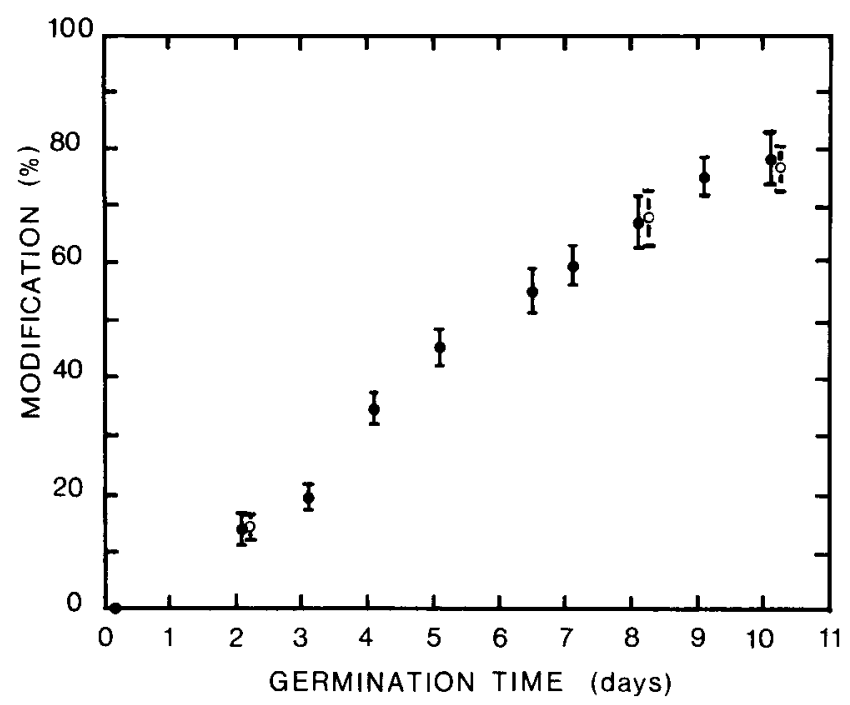

Figure 5. Relationship between germination time and average endosperm modification percentage $\left(\mathrm{M}_{\mathrm{a}}\right)$.

- : $\mathrm{M}_{\mathrm{a}}, \mathrm{n}=50$ - sample I; $\mathrm{O}: \mathrm{M}_{\mathrm{a}}, \mathrm{n}=50-$ sample II; $I$ : $95 \%$ confidence limits of average sample I; $\bar{\Phi}: 95 \%$ confidence limits of average sample II. average were calculated for each sample (Table I). The relationship between these parameters and the germination time (Figure 5) showed that progressive germination can be characterized by an increase in $\mathrm{M}_{\mathrm{a}}$. The reproducibility of the method was tested when duplicate samples of 50 seeds taken after two, eight and ten days of germination were analysed (Table I and Figure 5). T-tests showed no significant differences between these duplicate measurements with regard to $\mathrm{M}_{\mathrm{a}}$ or to the distribution pattern. This result verified that a sample size of 50 seeds was sufficient to obtain a reproducible estimate of modification. 30 seeds, however, gave $\mathrm{M}_{\mathrm{a}}$ 's very close to those of 50 seeds, e.g. from germination day eight the results were $M_{a}=67.8 \pm 6.9$ and $67.2 \pm 4.9$ for the measurements based on 30 seeds and 50 seeds, respectively. Generally the sample size is determined by the standard deviation (s) as the $95 \%$ confidence limits of average is $M_{a} \pm 2 s \sqrt{n}$. This means that in malt samples showing a large variation in $\mathrm{M}_{\mathrm{i}}$, the sample size must be large.

The observed variability in modification at any one day cannot be simply explained. Although the ability of small seeds to germinate rapidly is a well established phenomena, in the present experiment and indeed in the majority of commercial malthouses, only seeds greater than 

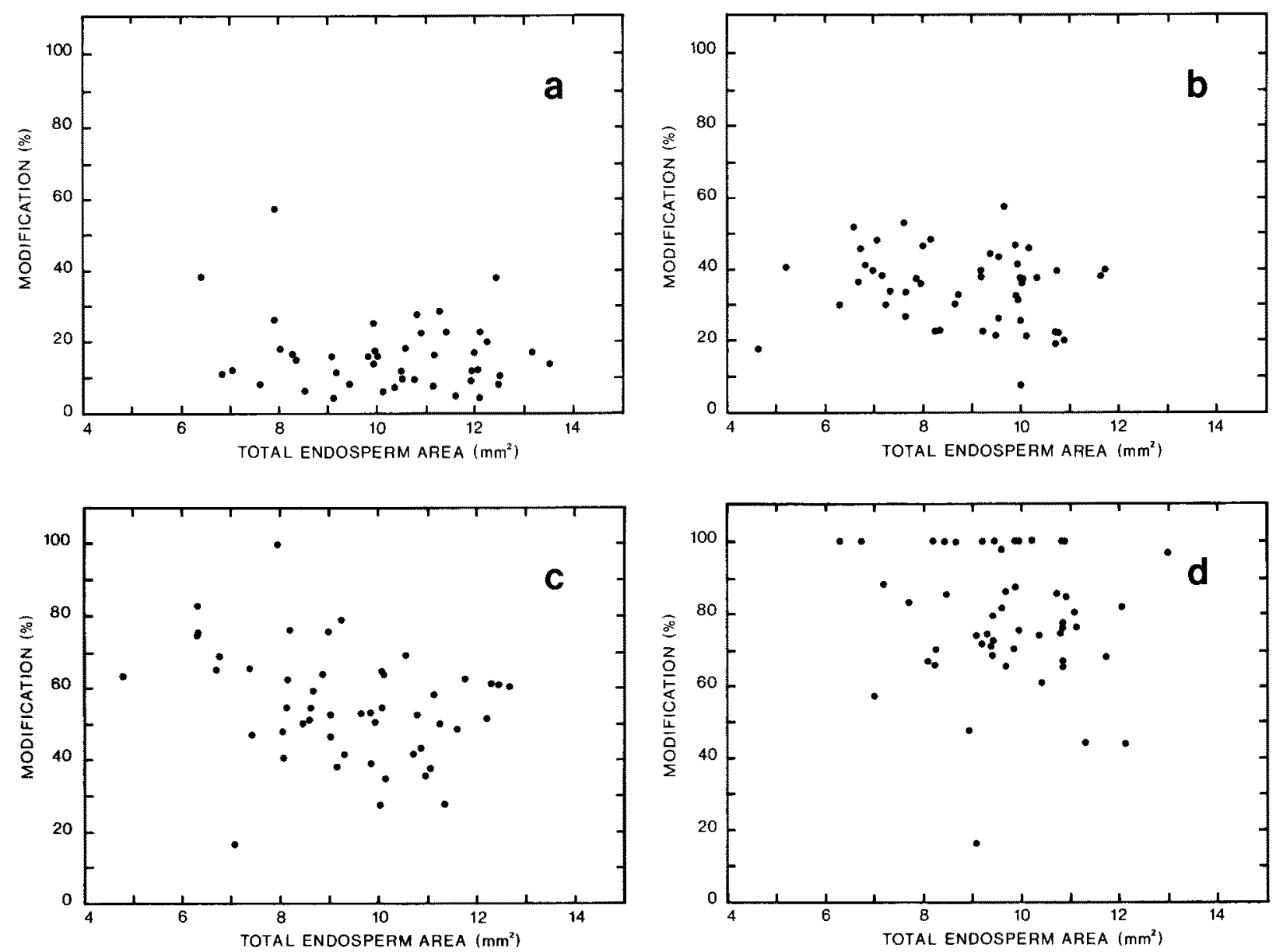

Figure 6. Relationship between total endosperm area and endosperm modification percentage $\left(\mathrm{M}_{\mathrm{i}}\right)$.

Germination time: 2 days (a), 4 days (b), $6 \%$ days (c) and 10 days (d).

$2.5 \mathrm{~mm}$ in diameter are used for malting purposes. The possible effect of seed size on the modification percentage has therefore been investigated. The data from all germination days indicated only a slight non-significant tendency of the smaller seeds to germinate more rapidly. The relationship between seed size and modification at $2,4,6 \frac{1}{2}$ and 10 days are shown in Figure 6 .

\subsection{Modification percentage related to other modification parameters}

\subsubsection{Acrospire length}

In the malthouse the acrospire length is used as an indicator of endosperm modification (Table I). The overall correlation between $M_{i}$ and acrospire length of seeds from the third to tenth day of the pilot malting was surprisingly low with a correlation coefficient of $R^{2}=0.62$. All seeds with acrospire length equal to seed length were examined more closely. The $M_{i}$ values of these seeds (Figure 7) illustrated that even with a fully developed acrospire the $M_{i}$ values varied from $60 \%$ to $100 \%$. This result thus demonstrated a limited value of acrospire measurement as an indication of endosperm modification of single seeds.

\subsubsection{Total and water-soluble $\beta$-glucans}

As Calcofluor binds specifically to $\beta$-linked glucans (17) the relationship between $\mathrm{M}_{\mathrm{a}}$ and the residual $\beta$-glucan content was investigated (Table $I$ and Figure 8). Linear correlation gave a 


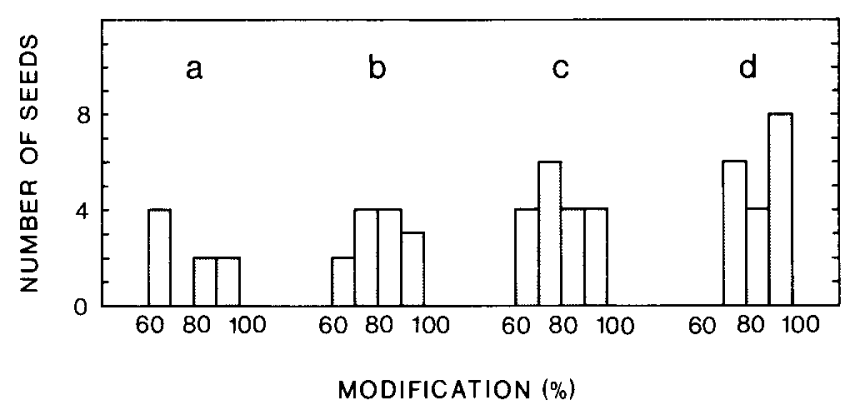

Figure 7. Distribution of endosperm modification percentage $\left(\mathrm{M}_{\mathrm{i}}\right)$ in seeds with acrospire length equal to seed length.

Germination time: 7 days (a), 8 days (b), 9 days (c) and 10 days $(d)$.

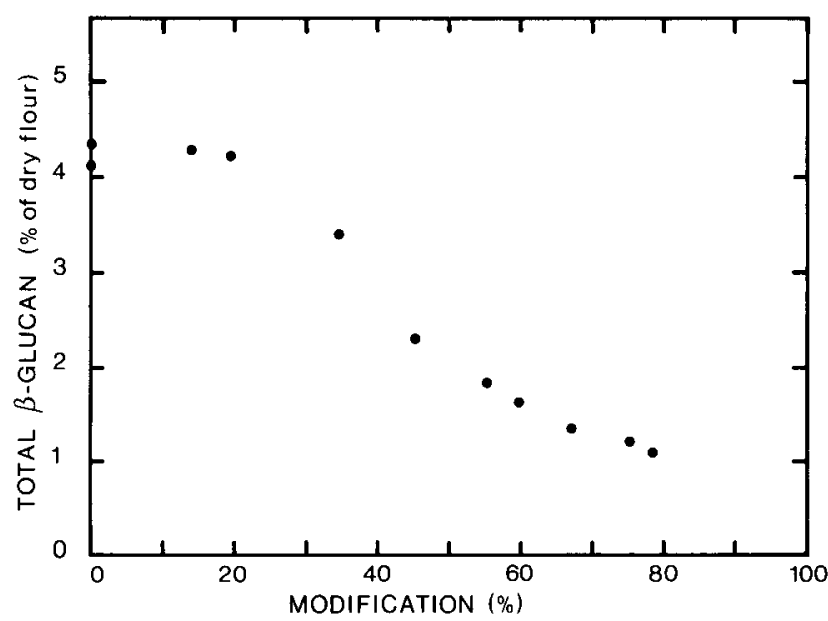

Figure 8. Relationship between average endosperm modification percentage $\left(\mathrm{M}_{\mathrm{a}}\right)$ and total $\beta$-glucan content.

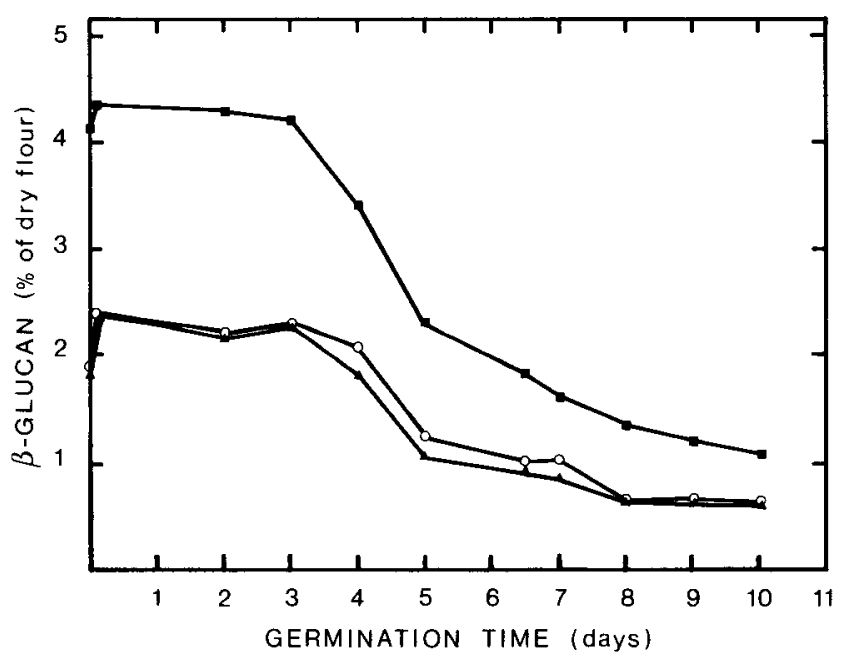

correlation coefficient of $R^{2}=0.95$. The correlation coefficient could be improved $\left(R^{2}=\right.$ 0.994) if the data were based on a third degree polynomium giving a sigmoid curve. A general conclusion about the exact relationship between $M_{a}$ and the total $\beta$-glucan content could not be drawn due to the relatively small amount of samples taken. It should be noted, however, that a linear relationship would not be expected as $\mathrm{M}_{\mathrm{a}}$, reflecting the result of enzymatic activity is based on area measurements whereas the determination of residual $\beta$-glucan is based on dry weight of seeds.

The water-soluble $\beta$-glucan content was also measured. Extractions were carried out at both $65^{\circ} \mathrm{C}$ and $75^{\circ} \mathrm{C}$ which are the most relevant temperatures for British and Danish brewing, respectively. The content of water-soluble $\beta$ glucans increased during the first two hours of steeping (Figure 9) in agreement with earlier findings (9). Both the total and the water-soluble $\beta$-glucans showed a minor decrease during the first three days of germination followed by a rapid fall from the third to fifth day. A slower decrease was observed from the fifth to the tenth day. It is notable that the percentage of soluble $\beta$ glucans was essentially the same throughout germination $\left(50 \%\right.$ and $55 \%$ at $65^{\circ} \mathrm{C}$ and $75^{\circ} \mathrm{C}$, respectively).

\subsubsection{Endo-ß-glucanase activity}

Endo- $\beta$-glucanase activity (Table I) was highly negatively linearly correlated to the total $\beta$ glucan content of the malt with a correlation coefficient of $R^{2}=0.98$. The relationship between $M_{a}$ and endo- $\beta$-glucanase activity (Figure 10) showed, as in the case of the relation between $M_{a}$ and the total- $\beta$-glucan discussed earlier, that the correlation coefficient was higher $\left(\mathrm{R}^{2}=0.985\right)$ when the relationship was based on a third degree polynomium than on a linear relationship $\left(\mathrm{R}^{2}=0.97\right)$.

Figure 9. Relationship between germination time and $\beta$-glucan content.

- - : total $\beta$-glucan content. O-O: watersoluble $\beta$-glucan content, $75^{\circ} \mathrm{C}$. $\Delta-\Delta$ : watersoluble $\beta$-glucan content, $65^{\circ} \mathrm{C}$. 


\subsection{Visual determination of modification}

Visual determination of modification by comparison to a known standard was tested as described in section 2.7. As a control the modification values determined by image analysis were used. The results (Figure 11) demonstrate a high accuracy of the visual modification analysis, which means that the method may be applicable in the practical control of malt.

\subsection{Endosperm modification during kilning}

During the initial stages of kilning, endo- $\beta$ glucanase activity was markedly reduced and endosperm modification continued (Table II). The malt analyses (Table III) showed that the final malt was slightly undermodified judged by the extract difference and the viscosity of the wort.

\section{DISCUSSION}

Malt quality is traditionally determined by malt analyses and a good malt is characterised by an empirical combination of optimal values for the measured parameters, e.g. extract content, extract difference and wort viscosity. The malting quality of a barley is a result of both genotype and environment, and many attempts have been made to determine this quality.

Simple tests such as the viscosity of acid flour extract $(1,15,18)$, milling energy (3) and barley flour sedimentation value (20) have been previously employed. However, one of the most important properties of a good malting barley is a rapid and even germination, which can neither be measured by classical malt analyses nor by barley tests. Most of these analyses are based on flour made from representative samples and thus represent mean values for all seeds in the

Table II

Endo- $\beta$-glucanase activity, $\beta$-glucan content and $M_{a}$ during kilning.

\begin{tabular}{lccc}
\hline \multicolumn{1}{c}{ Malt } & $\begin{array}{c}\text { Endo- } \beta \text {-glucanase activity } \\
\text { (arb. units) }\end{array}$ & $\begin{array}{c}\text { Total } \beta \text {-glucan } \\
(\% \text { of dry flour })\end{array}$ & $\begin{array}{c}\text { Endosperm modification \% } \\
\left(\mathrm{M}_{\mathrm{a}}, \mathrm{n}=50\right)\end{array}$ \\
\hline Green malt, 6.5 days & 1344 & 1.84 & $55.2 \pm 4.4$ \\
Kilned malt, $11 \mathrm{~h}, 50^{\circ} \mathrm{C}$ & 460 & 1.40 & $63.1 \pm 4.0$ \\
Final malt & 344 & 1.15 & $63.3 \pm 4.0$ \\
\hline
\end{tabular}

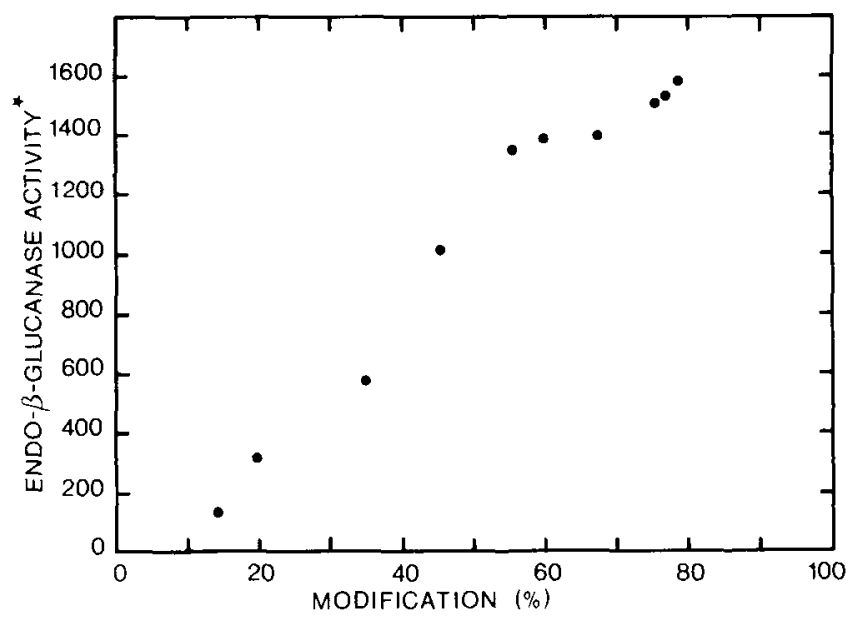

Figure 10. Relationship between average endosperm modification percentage $\left(\mathrm{M}_{\mathrm{a}}\right)$ and endo- $\beta$-glucanase activity.

* Arbitrary units

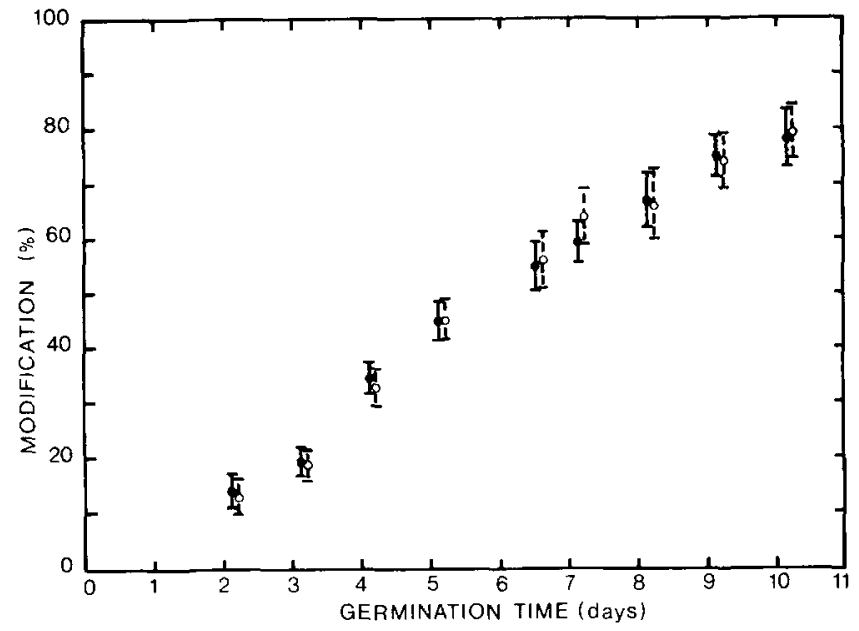

Figure 11. Relationship between germination time and average endosperm modification percentage $\left(\mathrm{M}_{\mathrm{a}}\right)$ determined visually by means of the Carlsberg Macrofluorescence Microscope $(\bar{c})$ and by image analysis (\$).

The height of the bars at each point represent the $95 \%$ confidence limits of average. 
Table III

Analyses of malt.

\begin{tabular}{lcc}
\hline & & $\begin{array}{c}\text { Specifications } \\
\text { for pilot malt }\end{array}$ \\
\hline Moisture content, \% & 4.8 & $<4.5$ \\
Extract content, fine grind, ${ }^{\circ}$ Plato & 79.4 & \\
Extract difference, ${ }^{\circ}$ Plato & 4.1 & $2.0-4.0$ \\
Nitrogen in malt, \% & 1.89 & \\
Diastatic power, Windisch-Kolbach units & 330 & \\
Kolbach index. \% & 33 & $2.8-4.0$ \\
Wort colour, EBC units & 2.8 & $1.50-1.70$ \\
Viscosity of wort, cP at $20^{\circ} \mathrm{C}$ & 1.74 & \\
Total $\beta$-glucan, \% & 1.15 & \\
\hline
\end{tabular}

samples while the determination of evenness and rapidness of germination must by nature rely on single seed measurements. The most commonly used method to measure these properties is the determination of the acrospire length (22), which has been believed to reflect the degree of endosperm modification. However, in the present study this could not be confirmed with regard to single seeds. A more direct way of estimating the endosperm breakdown was proposed (21), based on the assumption that the soft modified part of the endosperm can be extracted by hot water, while the intact endosperm is retained in the seed. Another single seed method has been developed using methylene blue (16). Seeds are cut in both ends and placed in a solution of methylene blue, which is believed to penetrate into the disintegrated part of the endosperm leaving the intact endosperm unstained. The penetration of methylene blue can then be visualized by cutting the seeds in halfs. The most exact way of determining the degree of endosperm breakdown is to specifically stain the modified or the unmodified endosperm. This has been effected by the use of histochemical reagents such as Congo Red (6) and Calcofluor $(12,26)$. It is of interest to note that the results obtained using endosperm stains indicate a different modification pattern to that observed with hot water washing.

Use of Calcofluor for measuring endosperm modification has been employed in the present study. The measurement of the modification percentage $\left(\mathrm{M}_{\mathrm{i}}\right)$ of the individual seeds from each germination day was shown to give a quantitative determination of modification and a clear picture of the evenness and rapidness of germination. The average modification percentage $\left(\mathrm{M}_{\mathrm{a}}\right)$ was found to be a good quantitative measure of the overall modification at a given day of malting. The $\mathrm{M}_{\mathrm{a}}$ was also found to be highiy correlated to the $\beta$-glucan content and the endo- $\beta$-glucanase activity. Use of the present method should then also allow measurement and control of residual $\beta$-glucan content in germinating barley. However, as the $\beta$-glucan content of barley varies considerably with genotype ( 1 ) and environment (2) the total $\beta$-glucan content of the ungerminated barley must be known.

\section{ACKNOWLEDGEMENTS}

The authors wish to thank Dr. LARs MuncK and Dr. Gregory C. Gibbons for support and critical reading of the manuscript. Professor Bruce A. Stone, La Trobe University, Melbourne, Australia, is gratefully acknowledged for stimulating discussions during his sabbatical stay at the Department of Brewing Chemistry. We also wish to thank J. Axel Sørensen for guiding the pilot malting experiment, LILLEMOR Frederiksen for skillful technical assistance, CAROL FEIL for providing the data programme, Lisbeth Sejersen and Lisbeth Grubov for carrying out the statistical analyses and ULLAKaRIN GibBons for drawing the figures. 


\section{REFERENCES}

1. Aastrup, S.: The relationship between the viscosity of an acid flour extract of barley and its $\beta$-glucan content. Carlsberg Res. Commun. 44, 289-304 (1979)

2. Aastrup, S.: The effect of rain on $\beta$-glucan content in barley grains. Carlsberg Res. Commun. 44, 381-393 (1979)

3. Allison, M. J., I. Cowe \& R. McHale:A rapid test for the prediction of malting quality of barley. J. Inst. Brew. 82, 166-167 (1976)

4. Analytica-EBC, Analysis Committee of European Brewery Convention, T.-M. Enari ed. Schweizer-Brauerei-Rundschau, 3rd ed., Zürich, 87 pp. (1975)

5. Anderson, M. A., J. A. CoOK \& B. A. Stone: Enzymatic determination of $1,3: 1,4 \beta$-glucans in barley grains and other cereals. J. Inst. Brew. 84 , 233-239 (1978)

6. Briggs, D. E.: Enzyme formation, cellular breakdown and the distribution of gibberellins in the endosperm of barley. Planta (Berl.) 108, 351-358 (1972)

7. Crabe, D. \& G. N. Bathgate: The influence of $\beta$-glucanase on efficiency of wort separation. J. Inst. Brew. 79, 519-525 (1973)

8. Erdal, K. \& P. Guertsen: $\beta$-glucans in malting and brewing III. The action of endo- $\beta$-glucanases. Eu. Brew. Con. Proc. Cong., Estoril 1971, 49-57 (1972)

9. Forrest, I. S. \& T. Wainwright: Differentiation between desirable and troublesome $\beta$ glucans. Eu. Brew. Con. Proc. Cong., Amsterdam 1977, 401-413 (1977)

10. Fulcher, R. G. \& S. I. Wong: Inside cereals - A fluorescence microchemical view. Proc. Intl. Conf. Cereals for Food and Beverages. Acad. Press., New York, 1-26 (1980)

11. Gibions, G. C.: On the location and transport of $\alpha$-amylase during germination and early seeding growth of Hordeum vulgare. Carlsberg Res. Commun. 44, 353-366 (1979)

12. Gibbons, G. C.: On the sequential determination of $\alpha$-amylase transport and cell wall breakdown in germinating seeds of Hordeum vulgare. Carlsberg Res. Commun. 45, 177-184 (1980)

13. Gibbons, G. C. \& L. Munck: Swedish patent application No. 790491-1 (1979)
14. GJERTSEN, P.: $\beta$-glucans in malting and brewing I. Influence of $\beta$-glucans on the filtration of strong beers. Am. Soc. Brew. Chem. Proc. 1966 , 113-120 (1966)

15. Greenderg, D. C. \& E. T. Whitmore: A rapid method for estimating the viscosity of barley extracts. J. Inst. Brew. 80, 31-33 (1974)

16. Kringstad, H.: Use of colour indicators as test for the modification of malt. Eu. Brew. Con. Proc. Cong., Interlaken 1969, 131-138 (1970)

17. MAEDA, H. \& N. Ishida: Specificity of binding of hexapyranosyl polysaccharides with a fluorescent brightener. J. Biochem. 62, 276-277 (1967)

18. Morgan, A. G.: The relationship between barley extract viscosity curves and malting ability. J. Inst. Brew. 83, 231-234 (1977)

19. Munck, L., C. Feil \& G. Gibbons: Analysis of botanical components in cereals and cereal products - A new way of understanding cereal processing. Proc. Intl. Conf. Cereals for Food and Beverages. Acad. Press., New York, 27-40 (1980)

20. Palmer, G. H.: A rapid guide to endosperm malting potential of barleys using a sedimentation procedure. J. Inst. Brew. 81, 71-73 (1975)

21. Palmer, G. H.: A method for direct assessment of malt modification. J. Inst. Brew. 81, 408-409 (1975)

22. Pawlowski - SchILD: Die Brautechnischen Untersuchungsmetoden. III. Malz und Würze. 8. Auflage, Verlag Hans Carl, Nürnberg, pp. 126127 (1961)

23. Preece, I. A.: Non-starchy polysaccharides of barley and their influence on wort composition. Eu. Brew. Con. Proc. Cong., Brighton 1951, 213-217 (1951)

24. Preece, I. A. \& K. G. Mackenzie: Non-starchy polysaccharides of cereal grains I. Fractionation of the barley gums. J. Inst. Brew. 58, 353-362 (1952)

25. Sandegren, E. \& L. Enebo: Cell wall decomposing of barley and malt I. Determination and stability investigation. J. Inst. Brew. 58, 198203 (1952)

26. WOOD, P. J. \& R. G. FulChER: Interaction of some dyes with cereal $\beta$-glucans. Cereal Chem. $55,952-966$ (1978) 